\title{
Wkład kapłanów zakonnych w kształtowanie się liturgicznego kultu Serca Jezusa
}

Inspiracją do napisania artykułu stały się słowa proboszcza z Ars św. Jana M. Vianneya (1786-1859), które przypomniał nam Ojciec Święty Benedykt XVI, ogłaszając oficjalnie rok kapłański w piątek 19 VI 2009 z okazji 150. rocznicy dies natalis świętego, który - jak pisze papież - „zwykł był mawiać: «Kapłaństwo to miłość Serca Jezusowego»”. Papież precyzuje, że to wyrażenie Vianney łączył z „,przebiciem Serca Chrystusa i oplatającą Go koroną cierniową", dlatego sam odnosi tę myśl do licznych kapłanów doświadczających niezrozumienia, odrzucenia czy prześladowania z powodu swej posługi ${ }^{2}$. Wyrażając świadomość potrzeby posługi kapłańskiej u św. proboszcza z Ars oraz jej wielkość, Benedykt XVI cytuje Bernarda Nodeta, który przytacza jedną z wielu wybranych myśli świętego: „Dobry pasterz według Bożego serca jest największym skarbem, jaki dobry Bóg może dać parafii i jednym z najcenniejszych darów Bożego miłosierdzia"3.

Rewolucja we Francji skutecznie tłumiła wszelkie praktyki religijne, w tym również sakramentalną spowiedź. A jednak dzięki temu, iż ks. Vianney długo trwał na modlitwie przed tabernakulum oraz był gotowy

${ }^{1}$ Benedykt XVI, List na rozpoczęcie roku kapłańskiego z okazji 150. rocznicy dies natalis świętego proboszcza Ars, Kraków 2009, s. 5. Zakończenie roku planowane jest w uroczystość Najświętszego Serca Pana Jezusa 2010 roku. Słowa te cytuje także Katechizm Kościoła Katolickiego, 1589.

2 Tamże, s. 6-7.

${ }^{3}$ Tamże, s. 8. Myśl ta zawarta jest w: B. Nodet, Le curé d'Ars. Sa pensée - son coeur, prés. par B. Nodet, Paris 1995, s. 101 (Foi Vivante. Témoins, 23); Myśli. Św. Jan Vianney proboszcz z Ars, wstęp i wybór B. Nodet, tł. H. Sobieraj, Paryż-Kraków-Kijów 2000 (Żywa Wiara. Świadkowie, 32). 
wysłuchać każdego, odkrywał przed ludźmi sens i piękno pojednania z Bogiem, tak że z całej Francji garnęły się tłumy do kratek jego konfesjonału i nieraz musiał spowiadać po kilkanaście godzin dziennie ${ }^{4}$.

Święty proboszcz z Ars działał w czasie rozkwitu nabożeństwa i liturgicznego kultu Serca Jezusowego. Pomimo że nie przyczynił się do powstania żadnego formularza mszalnego, to jednak jego słowa - cytowane przez papieża - inspirują, by spojrzeć na tych kapłanów, którzy w większości przynależeli do zakonów lub zgromadzeń i dodatkowo naznaczeni charyzmatem swego założyciela mieli znaczący wpływ na kształtowanie się tego kultu w historii. W niniejszym opracowaniu zajmiemy się okresem sięgającym do tak zwanych „wielkich objawień" (1673-1675) św. Małgorzaty Marii Alacoque. Rola magisterium Kościoła oraz wielu kobiet (przeważnie zakonnic), choć znacząca, oczywista i aprobująca, nie wchodzi do naszego tematu

Pierwsze przejawy działalności pisarskiej poświęconej kultowi Serca Jezusa

Pierwsze naukowe dzieło wyszło spod pióra abbé Julesa Thomasa ${ }^{6}$, natomiast J.-B. Anyès, przyjaciel św. Franciszka Borgiasza i św. Teresy Wielkiej, w 1550 roku wydał w Walencji dziełko zatytułowane Septem horae ad Christi cor, perstringentes praecipuos Passionis Domini actus ab eius captione in sepulturam, będące rodzajem małego oficjum o Najświętszym Sercu, które dzisiaj jest uważane za najstarszy i najcenniejszy dokument nabożeństwa do Najświętszego Serca Jezusa w Hiszpanii. Oficjum to, prócz modlitw, ma charakter wiersza. Zgodnie z tytułem zawiera siedem godzin, a każda mała godzina posiada pięć wierszy zawierających zawsze odniesienie do Najświętszego Serca oraz do jednej ze scen męki Jezusa, wezwanie wraz z odpowiedzią oraz niezmienną końcową modlitwę. Najbardziej miarodajną, obrazującą całość godziną jest matutinum, które mówi o agonii Jezusa, bogactwie Serca Syna Bo-

${ }^{4}$ Por. Benedykt XVI, List na rozpoczęcie roku kapłańskiego..., dz. cyt., s. 15.

${ }^{5}$ Szerzej o kulcie Serca Jezusa zob. W. Mocydlarz, Serce Jezusa w liturgii, Kraków 2009.

${ }^{6}$ Chodzi o La théorie de la dévotion au Sacré-Cour de Jésus d'après les documents authentiques et les sources originales, Lille 1885, 1912²; por. J. V. Bainvel, Kult Serca Bożego: teorja i rozwój, przeł. z fr. K. Dembowski, Kraków 1934, s. 7. 
żego otwartego włócznią żołnierza oraz nadziei modlących się na to, że będą godnymi chwały zmartwychwstania.

\section{Przedstawiciele benedyktynów i cystersów}

Tradycja monastyczna benedyktynów, a także cystersów oraz ich duchowość dały pierwszy bodziec i przygotowały przyszły rozwój nowej pobożności, która wychodząc od analizy tekstów skrypturystycznych i patrystycznych, zaczęła zwracać się do Serca Jezusa. Mamy tu bogactwo opracowań i dokumentacji historycznych powiązań z nabożeństwem i kultem Serca Jezusa ${ }^{8}$.

Najczęściej komentowano wówczas następujące teksty: Latus eius aperuit (J 19,34), Recubuit super pectus eius (J 21, 20), Vulnerasti cor meum (Pnp 4, 9), In foraminibus petrae (Pnp 2, 14 - „w zagłębieniach skały”), Haurietis aquas (Iz 12,13) oraz Mitis et humilis corde (Mt 11, 29).

Benedyktyn Rupert z Deutz († 1129) łączyłtekst J 19, 34 z Rz 6, 4, mówiąc o Ukrzyżowanym i Jego ranie, tj. boku przeszytym (otwartym) włócznią, z którego rodzi się Kościół (nowa Ewa z Adama) i sakramenty, zwłaszcza chrzest, który jest nowym exodusem. Podkreślał przy tym miłość Jezusa przelewającego dla nas krew, by uwolnić nas z grzechów (por. Ap 1,5)․ Z kolei mnich Drogon († 1137) czynił aluzję do Ez 47, 2, a ranę boku, z której wypływa symbol zbawienia (woda jakby „spod narożnika świątyni”), przyrównywał do bramy w arce, która ocaliła Noego od potopu ${ }^{10}$.

${ }^{7}$ Poświęcone ono zostało „bliskiej krewnej św. Franciszka Borgiasza, ksieni klasztoru Sainte-Claire w Gandji” - J. V. Bainvel, Kult Serca Bożego: teorja i rozwój, dz. cyt., s. 289-290; por. N. Nilles, De rationibus festorum Sacratissimi Cordis Jesu et purissimi cordis Mariae, Oeniponte 1885, t. 2, s. 221-223.

${ }^{8}$ Por. J. Leclercq, Le Sacré-Coeur dans la traditions bénédictine au moyen âge, [w:] Cor Jesu. Commentationes in litteras encyclicas Pii pp. XII «Haurietis aquas», quas peritis collaborantibus ediderunt A. Bea, H. Rahner, H. Rondet, F. Schwendimann, t. 2, Roma 1959, s. 3.

${ }^{9}$ Por. tamże, s. 6-7.

${ }^{10}$ Por. tamże, s. 7-10. Podobnie porównanie do bramy arki czyni Guillaume z Saint-Thierry († 1149), dodając tylko, że Serce Jezusa, w którym kryją się niezgłębione bogactwa Jego chwały (por. Ef 3, 8), jest naczyniem zawierającym mannę Bożą. Natomiast dla Egberta z Schönau Jezus jest źródłem promieniowania Serca Boga na wysokości, a woda wypływająca z boku to Jego miłość. Także Arnoud z Bonneval pogłębia symbolikę chrzcielną wody wypływającej z boku Pana, a „wytryskującej ku życiu wiecznemu", o której mówił Jezus przy studni Jakuba do Samarytanki (J 4, 14). Są one 
Benedyktyn Geoffroy d'Admont († 1165) komentował tekst J 21, 20 (w nawiązaniu do J 13, 23) o umiłowanym uczniu spoczywającym na piersi Pana (dla niego - symbol Pisma Świętego) podczas ostatniej wieczerzy, co umożliwiło uczniowi zgłębienie tajemnic Pana i przekazanie nam tych poznanych treści. Podobnie jak Pismo Święte posiada ukryty sens duchowy, umożliwiający człowiekowi wewnętrzne życie, tak i Serce Jezusa jest nośnikiem życia ${ }^{11}$.

Komentatorzy tekstu z Pnp 4, 9 podkreślają, że chodzi o ranę miłości, którą Oblubieniec otrzymuje od oblubienicy. Honorius Augustodunensis (†1156) twierdzi, że to Serce, w którym niejako miłość rezyduje, zawiera miłość osoby Oblubieńca (Chrystusa na krzyżu obdarzającego hojnie łaską zadośćuczynienia) do oblubienicy będącej w potrzebie (Kościoła) ${ }^{12}$.

Dla cystersa św. Bernarda z Clairvaux († 1153) szczelina w skale (Pnp $2,14)$ to rany łaski Pana, współczucia, bogactwa dobroci (także Ojca) i zamiarów Jego Serca, objawienia Jego „wnętrzności miłosierdzia” (Kol 3, 12), rany będące znakiem wynagrodzenia, jakie wypływa ze zmartwychwstania. Bernard precyzuje, dostrzegając w otwarciu skały (szczeliny), którą jest Słowo Boga, nie tylko źródło narodzin Kościoła, lecz także możliwość poznania i oglądania chwały Oblubieńca (Chrystusa) i Jego Ojca ${ }^{13}$.

Także cysters Guerric z Igny ( $† 1157)$ zajmuje się życiem wewnętrznym Jezusa, które nazywa forma cordis, forma spiritualis Christi. Natomiast dzięki forma corporis w tej naturze ludzkiej mamy dostęp do życia Bożego. Guerric mówi o ukryciu się w ranach, w ranie Jego boku, których figurą tylko były arka i jej brama, a bok przebity (pełen miłości, miłosierdzia,

wodami uzdrowienia, skruchy (pokuty). Natomiast Adam z Pereigne (koniec XII wieku) wskazuje na obfitość darów wypływających z rany Pana: wylanie Ducha Świętego i bogactwa łask, które zostały złożone w Kościele.

${ }^{11}$ Por. tamże, s. 11-12. Z kolei Gilbert z Hoyland († 1172) podkreśla mocno uprzednią miłość Pana w stosunku do każdej duszy, nawiązując tu do $1 \mathrm{~J}$ 4, 10, jak również obopólną wymianę miłości pomiędzy nią a Chrystusem.

${ }^{12}$ Por. tamże, s. 12.

${ }^{13}$ Por. tamże, s. 15-16. Bernard z Clairvaux, ur. w Fontaine-Leś-Dijon 20 VIII 1090, zm. w Clairvaux 20 VIII 1153, używa w swoich dziełach zwrotów związanych z „sercem" (zwroty te występują także w hymnach z XIII wieku jemu przypisywanych, choć nie są jego autorstwa): bok zraniony - Salve, latus Salvatoris, pierś - Salve, salus mea [...] pectus, serce - Summi Regis cor, aveto; w Sermo 61 super Canticum Bernard mówi o ranach Zbawiciela, a zwłaszcza o ranie boku, a kilka wierszy odnosi wprost do Serca Jezusowego - por. J. V. Bainvel, Kult Serca Bożego: teorja i rozwój, dz. cyt., s. 256, 258-260, 269. 
słodyczy duchowych) - z którego wypływa zbawcza rzeka - daje nam to, co figura zapowiadała ${ }^{14}$.

Św. Bernard, opat z Clairvaux, komentował także tekst Iz 12, 13. W źródłach Zbawiciela widział zbawczą (rajską - Rdz 2,10) rzekę, która dla nas została odtworzona w piersi Pana. Jej cztery rozdzielające się ramiona w Edenie to działanie czterech cnót, z których wypływa miłość. Z tego źródła jak z Ducha miłości mamy zaczerpnąć (nawiązanie do J 7,37.39), by kochać Boga i bliźniego. To Jezus jest tym naszym rajem (paradisus noster Christus) ${ }^{15}$.

Św. Bernard często cytuje Mt 11, 29, kładąc większy nacisk na cnoty, których Chrystus nauczał, a które posiadał w swym Sercu. Upodobnić się do Niego oznacza zostać ukształtowanym na wzór Jego pokornego Serca, w którym objawia nam pełnię swej dobroci oraz Ojca (Jego „zamysły pokoju”), ponieważ wszystko, co Syn daje, „otrzymuje On z Serca Ojca”: ,pochodząc z Serca swego Ojca, On naprawdę pokazuje nam Jego wnętrzności miłosierdzia"16.

Trzeba także wspomnieć Benedykta Haeftena (1587-1648), benedyktyna, opata w Afflighem (Holandia), który w L'École du coeur (1629) mówi o ranie boku, streszczając całą wielką myśl tradycji. W głębi rany odnajduje Serce, w którym trzeba „rozbić swój namiot” albo zbudować w nim swe mieszkanie, złączyć swe serce z Jego Sercem, zamiast ręki włożyć weń serce swoje. Serce Jezusa (płonące, pełne słodyczy) jest dla niego „pierwowzorem własnego serca" ${ }^{17}$.

${ }^{14}$ Guerric żył pod koniec XII wieku, był opatem w Citeaux i autorem De praeparatione cordis - por. J. Leclercq, Le Sacré-Coeur dans la traditions bénédictine au moyen âge, art. cyt., s. 16. Thomas de Perseigne zauważa, że przez ranę boku płynie modlitwa pochodząca z Najświętszego Serca, a krew pochodząca z ran puryfikuje twarz (rozumianą jako sumienie) oblubienicy.

${ }^{15}$ Por. tamże, s. 17-18. Adam z Perseigne zastosował do piątej rany (boku) Zbawiciela Iz 12, 13, wprowadzając nowe elementy: pozostałe rany, myśli (zamiary Serca), wodę i olej oraz strumień wina - symbol „powściągliwej miłości”. W przyszłości autorzy będą rozwijać temat mistycznej winorośli. Adam z Perseigne zastanawia się, jak we wzajemnej miłości „kochać z wiernością i być kochanym”. Odpowiadając na miłość umierającego Zbawiciela, mówi o dostosowaniu pewnego uczucia współcierpienia.

${ }^{16}$ Tamże, s. 19. W medytacji o męce Egbert z Schönau widzi w ranach Pana, w ranie boku, dowody tej pokory Serca i tej słodyczy, które pchnęły Jezusa, by nas ukochać i by cierpieć za nas.

${ }^{17}$ Por. J. V. Bainvel, Kult Serca Bożego: teorja i rozwój, dz. cyt., s. 310-312, 544, 546. 


\section{Ujęcie kultu Serca Jezusa u dominikanów}

Kluczem do zrozumienia Zakonu Kaznodziejskiego jest pojmowanie głoszonego słowa w relacji do Serca Bożego u św. Dominika, który dla posługi słowa („którym miłość oddycha”) jako pasterz i przewodnik ludu Bożego założył nowy zakon kaznodziejski. Sam najpierw rozważał Słowo Wcielone pełne łaski i prawdy $(\mathrm{J} 1,14)$, potem dopiero mówił o nim w kazaniu. W medytacji nad Mt 11, 29 odkrywał "ciche i pokorne serce” Zbawiciela, by takie stawiać innym za wzór do naśladowania, zwłaszcza swoim nowicjuszom. Dominik wiele godzin spędzał na nocnym czuwaniu przed ołtarzem, adorując w miłości rzeczywiście Obecnego w tabernakulum. Jako chrześcijanin i kapłan starał się w kontemplacji ostatniej wieczerzy poszerzyć horyzont rozumienia i miłości eucharystycznego Serca Jezusa, przeniknąć do cierpiącego i nasyconego wyszydzeniem Serca Zbawiciela, posłusznego aż do śmierci, po niej nawet przebitego oraz zachowującego swe rany po zmartwychwstaniu ${ }^{18}$.

W gronie wielu czcicieli Serca Jezusa w Zakonie Kaznodziejskim ${ }^{19}$ zaszczytne miejsce zajmuje Albert Wielki. Jeszcze przed znanymi dziełami mistyczek z Helfty pozostawił nam wiele odniesień do zamysłów Najświętszego Serca w komentarzach do czterech Ewangelii i do sentencji, w teologicznych sumach, w pismach o mszy świętej i o sakramencie ołtarza. Zebrane razem pozwalają zaprezentować jego myśl i naukę o Najświętszym Sercu. Jest ona odbiciem średniowiecznego rozumienia Serca Jezusa, a czerpie z patrystycznych tradycji. Albert łatwo znajduje drogę do Serca Jezusa, gdyż odwrotnie niż Tomasz, dogłębnie wypatruje i akcentuje to, co cielesne i fizjologiczne w ciele człowieka. W analizie pojęć „serce" $i$,,serce Jezusa" przeważają u niego wąskie, przyczynowe zależności pomiędzy tym, co fizyczne, a tym, co duchowe (naturalne

${ }^{18}$ Por. A. Walz, Dominikanische Herz Jesu-Auffassung, [w:] Cor Jesu. Commentationes in litteras encyclicas Pii pp. XII «Haurietis aquas», dz. cyt., t. 2, s. 51-53 i 58. Pius XII w encyklice Haurietis aquas cytuje w rozdziale piątym słowa Alberta: „non minima eius Cordis particula est eucharistia“.

${ }^{19}$ Wymieńmy wśród nich Jordana z Sachsen († 1237), jego przyjaciela Henryka z Köln, dalej Tomasza z Cantimpré z jego dziełkiem Bonum universale de apibus, Arnolda z Freiburga, gorliwego duszpasterza Waltera ze Strassburga, następnie Henryka z Halle, Hermanna z Lipska i Dietricha z Apolda - por. J. Leclercq, Le Sacré-Coeur dans la traditions bénédictine au moyen âge, art. cyt., s. 53-55. 
i nadprzyrodzone). Albert akcentuje także to, co emocjonalne, traktując naukę Bożą jako theologia mentis et cordis, stawiając ją pomiędzy tym, co spekulatywne, i tym, co praktyczne. Powinna więc ona dostarczać zarówno wyniki, jak również formować dobrych chrześcijan ${ }^{20}$. Albert jest przeniknięty tajemnicą wcielenia Syna Bożego dla wyzwolenia nas z niewoli grzechu, dostrzega miłość Serca Zbawiciela i jej skutek - miłosierdzie Serca przepełnionego bólem nad upadłą ludzkością. Jest ono siedliskiem i symbolem mądrości, jak u Orygenesa i w starożytnych tekstach liturgicznych czerpiących obficie z Ewangelii św. Jana ${ }^{21}$.

W nauce o Sercu Jezusa najbardziej będzie się podkreślać miłość Bożą, a następnie miłość ludzką Zbawiciela. Odwieczna, sprawcza miłość Boża kształtuje i podnosi to nabożeństwo do latreutycznego kultu, pozwala Osobie Słowa przyjąć ludzkie ciało, wypełnić do końca zbawcze dzieło Boże ${ }^{22}$.

Św. Tomasz z Akwinu na łożu śmierci, wyznając swą miłość Chrystusowi, kreśli zarazem piękny hymn Adoro Te devote, skierowany do Chrystusa eucharystycznego, w którym znajdziemy ślad nabożeństwa do Serca Jezusa i Jego ran: ,jak niewierny Tomasz twych nie szukam ran” ${ }^{23}$.

${ }^{20}$ Por. tamże, s. 55-56.

${ }^{21}$ Por. tamże, s. 59-62. W nauczaniu św. Alberta znajdują się wszystkie elementy, które określają teologiczną treść nabożeństwa do Serca Jezusa, przede wszystkim ogólny materialny przedmiot nabożeństwa, którym jest Osoba Jezusa Chrystusa. Ma on wielką cześć do świętego człowieczeństwa Syna Bożego, dlatego szczególnym obiektem materialnym jest dla niego fizyczne Serce Zbawiciela.

${ }^{22}$ Por. tamże, s. 62-63. Dla Alberta Bosko-Ludzkie Serce tworzy centrum zarówno nauki, jak i Jego kultu, to znaczy deklaracji wiary i teologiczno-dogmatycznych podstaw. W jego doktrynie zamysły (zamiary) Serca Jezusa jako symbol i narzędzie miłości tworzą wartość zbawczą, wyraźną, pełną, uzasadnioną i kompleksową syntezę tego, co w tym Sercu symboliczne i przyczynowe.

${ }^{23}$ Por. tamże, s. 63-67. Co do autentyczności i autorstwa tego rymowanego hymnu poświadczonego już od XIV wieku (melodię gregoriańską dodano w XVII wieku) nie ma już dziś wątpliwości - por. Zbliżam się w pokorze, [w:] B. Nadolski, Leksykon liturgii, Poznań 2006, s. 1729-1730; J. Siedlecki, Śpiewnik kościelny, Kraków 200740 , n. 230, s. 260261. Spośród wielu duchowych pisarzy dominikańskich, którzy w swej korespondencji, modlitwach, studiach i wypowiedziach mówią o Sercu Jezusa lub ranie boku (ranach) Zbawiciela, wymienia się: Piotra z Dacji († 1288), Colda z Coldicz i św. Klemensa w Pradze (1302-1326/1327), autora traktatu z 1312 roku De strenuo milite, Dominika Cavalca z Vico koło Pizy († 1342) oraz Venturino z Bergamo († 1346). 
Spotykamy także wśród przedstawicieli Zakonu Dominikanów tych, którzy zachęcali, by wejść do wnętrza ${ }^{24}$ poprzez Serce Jezusa. Wymieńmy tu choćby wielkich i znanych mistyków: Mistrza Eckharta (ok. 1260-1327/1328 w Kolonii), Jana Taulera (1294-1361) i Henryka Suso $(1300-1366)^{25}$.

Nowy bodziec dla rozwoju nabożeństwa do Serca Jezusa dał Ignacy Del Nente († 1648) uważany przez niektórych za największego znawcę na polu refleksji dotyczącej Serca Jezusa. Siódme rozważanie jego zbioru Solitudini dedykowane jest Sercu Jezusa i stanowi pierwszy traktat o Sercu Jezusa w Zakonie Kaznodziejskim. Dwa zdania jego modlitwy Anima Christi, które czerpią z łacińskich tekstów o Sercu Dzieciątka Jezus oraz o ukrzyżowanym i uwielbionym Zbawicielu, zwracają się wprost do Serca Jezusa: „Cor Christi vulnera me” oraz "Caritas Christi transforma me”. W nowym wydaniu Solitudini z 1892 roku opracowanym przez J. Didiota zostały zamieszczone kontemplatywne zamyślenia nad pełnym bólu Sercem Chrystusa, Jego ranami (także Boku), jak również nad radościami Serca Jezusa. Dzieło to pozwala odkryć tajemnice Bożego Serca i uczy, jak zaczerpnąć z tego źródła zbawienia i jak upodobnić się do Jezusa ${ }^{26}$.

${ }^{24}$ Do głębi, dosł. wnętrzności, łac. viscera, np. misericordiae lub pietatis, niem. Innerlichkeit.

${ }^{25}$ Por.J. Leclercq, Le Sacré-Coeur dans la traditions bénédictine au moyen âge, art. cyt., s. 67-78; J. V. Bainvel, Kult Serca Bożego: teorja i rozwój, dz. cyt., s. 240-242, 245-246, 293-295. Myśl tych mistyków kontynuowali ich spadkobiercy, których pociągała wewnętrznie perspektywa picia z Boku Ukrzyżowanego (Jan Dominici, † 1419), przedostania się i dotarcia przez ranę Boku do miłości otwartego Serca Jezusa, z którego wytryskują symbole chrztu i Eucharystii - woda i Krew (Antonin Pierozzi, † 1459; podobnie Hieronim Savonarola, † 1498), rozważania cierpień Chrystusa (Mateusz Carreri, † 1470), zwłaszcza przebicia Jego boku (Jakub Sprenger, † 1495) czy też bycia przyjacielem Serca Jezusa (Stefan Irmy, † 1475). Podobną drogą przenikania do głębin tajników Boskiego Serca idzie Ludwik z Granady (1505-1588) w swoim Leben Christi, traktując ranę Serca jako bramę do wnętrza.

${ }^{26}$ Dzieło nosi tytuł: Solitudini di sacri e pietosi affetti intorno a misterii di Nostro Signor Giesù e a Maria Vergine, Florencja 1643, następne wydania: 1645, 1650, 1774 i 1781; francuskie opracowanie J. Didiota ukazało się w Paryżu-Tournai w 1890 roku. Solitudini... z 1643 roku biorą pod uwagę raczej Serce w życiu Jezusa, a Solitudini... z 1645 roku bardziej cierpiące Serce Jezusa. Do tej duchowej tradycji Zakonu Kaznodziejskiego należą według Floranda spekulatywny mistyk Ludwik Chardon († 1651), wydawca Institutiones Taulera, oraz autor oryginalnego dzieła La croix de Jésus, który kieruje swą uwagę na ranę boku i Serca Jezusa, na Krew i wodę, które stąd wypływają, oraz na skarby miłości tego Serca; por. A. Walz, Dominikanische Herz Jesu-Auffassung, art. cyt., s. 78-80; J. V. Bainvel, Kult Serca Bożego: teorja i rozwój, dz. cyt., s. 330-331. 


\section{Kult Najświętszego Serca w rodzinie \\ zakonów franciszkańskich}

Zakon seraficki nie został założony w tym celu, by szerzyć to nabożeństwo, jednak przez swą jasną doktrynę i ascezę przyczynił się skutecznie w okresie średniowiecznej pobożności mistycznej (ok.1250-1350) do przyszłego rozwoju kultu Serca Jezusa. Miał na to wpływ szczególnie stosunek św. Franciszka do człowieczeństwa Jezusa Chrystusa (zwłaszcza Jego męki - rana boku) oraz odwzorowanie Ukrzyżowanego w życiu samego założyciela (stygmaty). Stąd bierze swe źródło franciszkańska kontemplacja cierpień i pięciu ran Chrystusa (w tym rany boku). Serce Jezusa zostaje uznane za syntezę i cel każdej postawy pobożności względem Zbawiciela ${ }^{27}$.

Teolog i mistyk wielkiego formatu św. Bonawentura z Bagnoregio (ok. 1217-1274) wywarł ogromny wpływ na pobożność ludową oraz ówczesną naukę chrześcijańską, gdyż ukształtował prawdziwą pobożność do Serca Jezusa w zakonie serafickim (dobrze rozróżniał i łączył relację „boku” $\mathrm{i}$,serca”), wskazał na cel i praktykę (dwa akty kultu - wybłaganie gorącej miłości dla oczyszczenia z grzechu oraz wypełnienie każdego życzenia Chrystusa, oddanie i uwielbienie Go), a także na podwójny przedmiot kultu, to znaczy Serce fizyczne i symboliczne. Natomiast fragmenty z jego dzieł, bardzo głębokie i oryginalne (aktualne), weszły do oficjum Kościoła na święto Najświętszego Serca Jezusa i są zachowane aż do dziśs ${ }^{28}$.

${ }^{27}$ Por. L. di Fonzo, G. Colasanti, Il culto del Sacro Cuore di Gesù negli ordini francescani, [w:] Cor Jesu. Commentationes in litteras encyclicas Pii pp. XII «Haurietis aquas», dz. cyt., t. 2, s. 99-105. W XIII wieku wzrasta u mistyków, teologów oraz kaznodziejów franciszkańskich zarówno włoskiego, jak i niemieckiego pochodzenia pragnienie, by poprzez kontemplację wnętrza świętego boku zgłębić także treść bogactw Serca Jezusa. Niewątpliwie należy do nich zafascynowany krzyżem ze szczególnym odniesieniem do świętych ran Antoni z Padwy (ok. 1190-1231). Zachęca on do ucieczki w te rany i do świętego boku (symbol otwartej bramy raju), z którego wypływa woda i krew - symbole sakramentów zbawienia (chrztu i Eucharystii).

${ }^{28}$ Chodzi o II czytanie w godzinie czytań z Opusculum 3, Lignum vitae, 29-30. 47, Opera omnia, 8, 79, [w:] Liturgia Godzin. Codzienna modlitwa ludu Bożego, t. 3: Okres zwykły. Tygodnie I-XVII, Poznań 1987, s. 519-520; por. L. di Fonzo, G. Colasanti, Il culto..., art. cyt., s. 105-109. Należy dołączyć także mniej znanych franciszkanów: Lamprechta z Regensburga, który około 1250 roku skomponował poezję alegoryczną o miłości duszy do niebieskiego Oblubieńca; Dawida z Augsburga (†1272), mistyka i kaznodzieję, który w swoich różnych pismach kontempluje na krzyżu przede wszystkim „rozpalone Serce 
W XIII i XIV wieku wypada powiedzieć o dziele Arbor Vitae crucifixae Iesu i nauczaniu Ubertino z Casale (1259-1330). Przez delikatne i ekspresyjne figury odkrywa on przede wszystkim niewyczerpaną miłość tego Serca Bożego (centrum zbawczego), nazywającje: ziemią błogosławioną, życiem nadprzyrodzonym dusz, sacrarium Trójcy, owczarnią dusz wybranych. Najświętsze Serce Boga-Człowieka od poczęcia aż do śmierci jest według niego siedzibą niezgłębionej miłości i bólu, ale również cudów dokonanych dla cierpiącej ludzkości. Ubertino wyróżnia siedem doskonałości Serca Jezusa: miłosierdzie, sprawiedliwość, mądrość, wiedzę, cierpliwość, moc (męstwo), gorącą miłość do Boga i do ludzi. Zachęca także i wskazuje praktyczne akty pobożności i miłości do Serca Jezusa: „oczyszczenie przygotowawcze z grzechów i wejście w cichy pokój tegoż Serca, akty dziękczynienia (wdzięczności) i miłosnego współczucia, gorące wezwania i wzdychania, myśl nieustannie zwrócona do Niego". Przypomina także o „miłości i obowiązku zadośćuczynienia”29.

W swoich kazaniach św. Bernardyn ze Sieny (1380-1444), wielki apostoł Włoch, wiele razy akcentuje kulminacyjny temat męki - przebite Serce Jezusa. On to został powieszony na drzewie krzyża i z jego wysokości wypowiada siedem słów, pragnie naszego zbawienia i modli się żarliwie za nas. Bernardyn mówi, że Ojcze nasz to „najpiękniejsza i droga relikwia", modlitwa, która wyszła ze środka Serca Pana ${ }^{30}$.

Do niego dołącza grupa kaznodziejów i mistyków niemieckich rodziny obserwantów: Henryk Herp (Harphius, † 1477), autor znanej Teologii mistycznej, który odkrywa miłość Chrystusa zranionego dla nas, by dać nam wejście do swego Serca; następnie Dietrich Coelde († 1515), któ-

Jezusa, z którego płynie krew ciepła miłości"; Bertolda z Ratyzbony, który przypomina, że podczas łamania hostii mamy do czynienia ze "słodkim i czystym Sercem Jezusa" zranionym przez włócznię przeszywającą bok; w Hiszpanii Rajmunda Lullo († 1315) dostrzegającego źródło i bramę uniwersalnego zbawienia, a w niej podwójną miłość Serca Jezusa rozdzieloną na dwie części przez włócznię; Jana Dunsa Szkota († 1308) z jego nauczaniem o absolutnym prymacie „ogromnej miłości Serca Jezusa” do Boga.

${ }^{29}$ Por. tamże, s. 112-115 i 118. We Włoszech inne znane i rozpowszechnione dzieło przywołuje życie, mękę, rany i zbliża się do źródła miłości Chrystusa. Są to Meditationes vitae Christi (ok. 1335) wcześniej przypisywane Bonawenturze, a teraz Toskańczykowi Giovanniemu z Calvoli, choć na pewno jeszcze nie wiemy, kto był autorem tego dzieła.

${ }^{30}$ Por. tamże, s. 118-120. Duży fragment z pism św. Bernardyna wchodził do brewiarza rzymskiego w homilii piątego dnia infra octavam święta Najświętszego Serca (zachowany aż do zawieszenia oktawy w 1955 roku). 
ry w podręczniku katechetycznym Christenspiegel (lustro chrześcijan) uczy wiernych, jak wyprosić w przebitym i wiernym Sercu Jezusa łaskę dobrej śmierci; dalej Fridolin, który nie odkrywa Najświętszego Serca poprzez ranę boku, ale w kontemplacji dobroci i wysublimowanych wielkości Chrystusa (wszystko: owoce męki, odkupienia, Eucharystii i innych sakramentów pochodzi i ,wychodzi z Serca Chrystusa” - Boga samego dzięki unii hipostatycznej) ${ }^{31}$.

Warto odnotować fakt, że około 1670 roku gwardian z konwentu w Caen Bernardo Chancerel uznał za wolne od błędów i zaaprobował modlitwy-pozdrowienia św. Jana Eudesa do Najświętszych Serc Jezusa i Maryi, zatwierdzając potem w szczególności w 1668 roku także kult i święto Serca Maryi dla zakonników i zakonnic franciszkańskich we Francji32.

\section{Wkład jezuitów w powstanie i rozwój kultu Serca Jezusa}

Jak pisze J. V. Bainvel: ,u kolebki Towarzystwa Jezusowego nie spotykamy [...] samego nabożeństwa [...]. Nie mamy żadnego pewnego dowodu historycznego na to, że św. Ignacy żywił to nabożeństwo w ścisłym tego słowa znaczeniu, a słynna modlitwa Anima Christi inflamma me istniała na długo przed św. Ignacym" ${ }^{33}$. Jest jednak prawdą, że konstytucje zakonu i Ćwiczenia duchowe Ignacego są odbiciem ducha miłości Jana

${ }^{31}$ Por. tamże, s. 120-128. Wymienia się jeszcze takie osobistości jak Kornel Musso z Piacenzy (1511-1574), Piotr Ridolfi z Tossignano († 1607), Józef du Tremblay z Paryża (1577-1638), „szara eminencja” we Francji, który ma częste odwołania do Najświętszego Serca, a którymi wzbudzał gorący kult, Leonard z Dijon (ok. 1598-1667) oraz Gulio z Besançon, Jan z Karthageny († 1617), reformata, Piotr z Alcantary (1499-1562), Jan Henry (Henricus) (†1558-1560), Piotr Wilhelm z Troyes, Bernardino z Osmo († 1591) ze swoim Tractatus de Passione Domini (Venetiis 1589), Tommaso z Bergamo (1563-1631), Lorenzo z Paryża († 1631) z dwoma dziełami: Le Palais d'amour divin de Jésus (1614) i Les tapisseries du divin amour, Bernardino z Paryża († 1658), o. Augustyn z Zamora w Hiszpanii, który w swoim tomie o sercu ludzkim „multa praelibavit de excellentiis divinissimi Cordis”; Adrien de Maringues, którego książka Exercices spirituales très utiles et propres pour conduire les âmes religieuses et séculières à la perfection des actions des jours, des semaines, des mois et des années ukazała się w Lyonie 1659 roku, św. Fidelis z Sigmaringen (1577-1622) w Niemczech, który zwraca swe uczucia do nieskończonej miłości i bólów najsłodszego Serca Jezusa - por. J. V. Bainvel, Kult Serca Bożego: teorja i rozwój, dz. cyt., s. 314, 335-336.

${ }^{32}$ Por. tamże, s. 129.

${ }^{33}$ J. V. Bainvel, Kult Serca Bożego: teorja i rozwój, dz. cyt., s. 371. 
Ewangelisty, ponieważ choć brak w nich samego słowa, to kierują dusze do Serca Bożego, podobnie jak np. u Franciszka Borgiasza ${ }^{34}$.

Baltazar Alvarez (1533-1580) uczy, że wchodząc początkowo do tajników Serca Boga-Człowieka, wstępujemy następnie do tajemnic Boga, który jest troisty w Osobach, a jeden w naturze ${ }^{35}$.

Kanizjusz (1521-1597) - uczeń Eschiusa (mistrza Mikołaja Van Esch) i przyjaciel Kartuzji Kolońskiej, od których zaczerpnął nabożeństwo do Serca Jezusa, już jako jezuita podczas swych uroczystych ślubów modlił się do Najświętszego Serca, pragnąc ugasić w Nim swe pragnienia. W modlitwie porannej i wieczornej stosował pozdrowienie Chrystusa autorstwa św. Mechtyldy, a w egzortach polecał współbraciom swoją wolę „łączyć [...] z sercem Jezusa”. Życie Kanizego, jego osoba wyraźnie świadczą o nabożeństwie do Serca Jezusowego wśród jezuitów ${ }^{36}$.

O. Hieronim Nadal (1507-1580) przez kilka lat był zaufanym, prawą ręką Ignacego, ,pozostawił także pewne rysy swego nabożeństwa do Najświętszego Serca”. W jego duchowych zapiskach czytamy: „Mając wrażenie, że Chrystus chce posłać swoje serce do serca swego sługi (missurum Christum cor suum ad eius cor), pytał z trwoga, czy myśl ta nie została mu poddana przez pyszne złudzenie (arroganter per illusionem). Uczuł wówczas, że Chrystus dał mu więcej jeszcze (plura): że nie tylko

${ }^{34}$ Por. tamże, s. 372-374; Acta Sanctorum, t. 33, s. 861.

${ }^{35}$ Por. J. V. Bainvel, Kult Serca Bożego: teorja i rozwój, dz. cyt., s. 297, który powołuje się na L. Du Pont, Vie du P. Balthasar Alvarez, traduite en francais par Marcel Bouix, Paris 1873, s. 24. Balthazar Alvarez, hiszpański mistyk i duchowy kierownik św. Teresy, urodził się w Cervera w Hiszpanii w 1533 roku, zmarł w Belmonte w 1580 roku - por. Bibliothèque de la Compagnie de Jésus, nouv. éd. par C. Sommervogel, t. 1, Bruxelles 1890, s. 222.

${ }^{36}$ Por. J. V. Bainvel, Kult Serca Bożego: teorja i rozwój, dz. cyt., s. 286- 287, 374, który powołuje się na Beati Petri Canisii, societatis Iesu, epistolae et acta, collegit et adnotationibus ill. O. Braunsberger, t. 1, Friburgi Brisgoviae 1896, s. 55, 58-59. Św. Piotr Kanizjusz (Piotr Kanizy, Peter Kanijs, właściwie Pieter de Hondt, ur. 8 V 1521 w Nijmegen, zm. 21 XII 1597 we Fryburgu), teolog i kaznodzieja, doktor Kościoła. W 1543 roku wstąpił do Towarzystwa Jezusowego, a w 3 lata później przyjął święcenia kapłańskie. Na polecenie św. Ignacego Loyoli przybył do Rzymu dla pogłębienia swej formacji duchowej. Wysłany do Niemiec, apostołował tam przez prawie 30 lat jako nauczyciel i kaznodzieja, odbudowywał struktury Kościoła, zakładał seminaria duchowne i prowadził bardzo ożywioną działalność pisarską. Spod jego pióra wyszły katechizmy, modlitewniki, kazania i szereg innych dzieł. Został beatyfikowany w 1864 roku przez Piusa IX, a kanonizowany i ogłoszony doktorem Kościoła w 1925 roku przez Piusa XI. Jego wspomnienie obchodzone jest 21 grudnia - por. Bibliothèque de la Compagnie de Jésus, dz. cyt., t. 2, s. 617-688. 
posłał mu swoje serce fizyczne, tj. swoją miłość stworzoną, lecz również swoje serce niestworzone i nieskończone" ${ }^{\prime 37}$.

W swoim dziele De inquisitione pacis sive studio orationis Alvarez de Paz (1560-1620) spotyka na swej drodze Zbawcę i sprowadza wszystko do obleczenia się w Jezusa, tj. do ukształtowania siebie na wzór Boskiego Mistrza. „Badanie i naśladowanie” oraz „uwielbienie” Bożego Serca traktuje jako środek do osiągnięcia podobieństwa do Jezusa. Następnie podaje modlitwę „o łaskę poznania i naśladowania Bożego Serca”. Zawiera ona błagania skierowane do przebitego Bosko-ludzkiego Serca: „Błagam cię, [...] wyciśnij serce moje na twoim przebitym sercu” oraz na końcu tej modlitwy: „Utwierdź serce moje tymi świętymi cnotami i umocnij je przez przytwierdzenie go do twego Najświętszego Serca"s8.

Trzeba wspomnieć A. Gaudiera (1572-1622) ze względu na jego dzieło La perfection de la vie spirituelle, gdzie w rozdziale o komunii świętej mówi o Sercu i zbawczej woli Jezusa, o pełnym zasług płomieniu gorącej miłości ku Bogu i ludziom, o tym, że „Jego Serce [...] zbliża się do naszego serca (naszej woli), [...] by zgładzić nasze grzechy, [...] by serce nasze żyło jego sercem i uczestniczyło w jego bożych doskonałościach, w jego radościach [...] i aby wola nasza przeszła w jego wolę i abyśmy w ten sposób stali się z nim i w nim jednym sercem, jedną duszą, byśmy mówić mogli: Żyję ja, już nie ja, ale żyje we mnie Chrystus" ${ }^{39}$.

${ }^{37}$ Cyt. za:J. V. Bainvel, Kult Serca Bożego: teorja irozwój, dz. cyt., s. 375-381; por. H. Nadal, [w: Bibliothèque de la Compagnie de Jésus, dz. cyt., t. 5, s. 1518-1520. W XVI wieku należy wymienić jeszcze: św. Alfonsa Rodrygueza, św. Alojzego Gonzagę, Franciszka Decostera, Salmerona, Toleta, Suareza, Ribadaneirę, natomiast w wieku XVII: Hieronima Diasa, Arnolda Catha, Jana Suffrena, Jana Rigoleuca, Antoniego de Padilla i Hieronima Ansaldiego. W dziele rozpowszechniania obrazków Najświętszego Serca przebitego włócznią z trzema gwoździami i pięciu ranami, które od XVI wieku było jakby szerokim prądem pociągającym i jezuitów do nabożeństwa, zasłużył się Desjardins, Grimouard de Sain-Laurent, a zwłaszcza Letierce.

${ }^{38}$ Alvarez idzie tutaj za Van Eschem (Eschiusem). Kiedy używał własnych słów, mówił: „Imprime sanctissimum cor tuum in cor meum”, a tu za Eschiusem: „Imprime cor meum in transfixum cor tuum" - cyt. za: J. V. Bainvel, Kult Serca Bożego: teorja i rozwój, dz. cyt., s. 381-383, 386. Całe to ćwiczenie duchowe podaje także N. Nilles, De rationibus..., dz. cyt., t. 2, s. 212-219.

${ }^{39}$ Cyt. za: J. V. Bainvel, Kult Serca Bożego: teorja i rozwój, dz. cyt., s. 386-387; por. A. Gaudier, [w:] Bibliothèque de la Compagnie de Jésus, dz. cyt., t. 3, s. 1265-1268. Oprócz autorów omówionych w tekście godni wymienienia są: Ludwik de Ponte (da Puente) (1545-1624) z jego Méditations zawierającymi wyjaśnienia o ranie boku i o ranie miłości, 
Pierwsze w swoim rodzaju praktyczne, a nie teoretyczne dzieło Kaspra Drużbickiego (1590-1662) Meta cordium cor Jesu jest wyjątkowo bogatym i głębokim podręcznikiem nabożeństwa do Najświętszego Serca. Już na karcie tytułowej odwołuje się on do tekstów Pisma Świętego (Pnp 8, 6; Prz 23, 26; Ps 64, 8). W przedmowie autor wyjaśnia, że są to Ćwiczenia ku czci Serca Jezusowego. Na te ćwiczenia składają się m.in. „małe godzinki do Serca Jezusowego, [...] modlitwy i westchnienia do Bożego Serca”, jak również punkty do codziennego rozważania: „o obowiązkach, uczuciach i cierpieniach tego Najświętszego Serca”. O. Kasper podaje także „środki zastosowania tego nabożeństwa w ćwiczeniach drogi oczyszczającej, oświecającej i jednoczącej; litanię ułożoną z obrazów i symbolów oznaczających to serce dla pomocy w rozmyślaniach i uczuciach; sposób przestawania z tym Najświętszym Sercem” oraz „nasze względem niego obowiązki”. To tylko niektóre z bogatych treści tego dzieła ${ }^{40}$.

Przed wielkimi i znanymi jezuitami J. Croisetem i J. Gallifetem Jakub Nouet (1608-1680) jest jednym z tych, którzy trafniej przedstawili teorię (syntezę) nabożeństwa do Serca Jezusa. Na początku trzeciej części w przedmowie książki L'homme d'oraison omawiającej chwalebne życie Chrystusa autor mówi wyłącznie o Jego przebitym boku i sercu fizycznym (wnętrzności), które zostało otwarte, „abyśmy mogli weń wejść i czerpać czystą miłość u samego źródła [...] w tym świętym sercu, której ta pierwsza jest symbolem (jest to całość nabożeństwa do Najświętszego Serca: teoria i praktyka); Ludwik Lallemant († 1635) i jego uczniowie, którzy wydali Doctrine spirituelle, zbierając w niej jego nauki i rady; Mateusz Hajnal (1578-1644) z traktatem Mała ksiązeczka do nabożeństwa dla serc kochających serce Jezusa...; Piotr Marie (1589-1645) z wydaną w 1642 roku La science du Crucifix, w której jest często mowa o Najświętszym Sercu; Wincenty Caraffa (1585-1649), który zostawił po sobie m.in. Droge do nieba i Considerations diverses sur les plaies du Christ; Paweł de Barry (1585-1661) z Le Paradis ouvert à Philagie, w której mówi o zadośćuczynieniu; Paweł Lejeune (1592-1664) oraz tacy pisarze jak: Suarez i Lugo; egzegeci: Maldonat, Tirinus Cornelius a Lapide, Lorin, Baeza; asceci: Scribani, Binet, Nieremberg, Jakób Rho, Leopold Mancini, Surin, Lyrée, Rigoleuc i inni, szczególnie zaś Jan-Chrzciciel de Saint-Jure (1588-1657) ze swymi dziełami Livre des élus, gdzie mówi o przebywaniu w ranach Jezusa, i L'homme spirituel oraz Jan Pullinus (1604-1671) wraz z książką Pia cum Jesu vulnerato colloquia - por. J. V. Bainvel, Kult Serca Bożego: teorja i rozwój, dz. cyt., s. 388-404, 406-409.

${ }^{40}$ Por. J. V. Bainvel, Kult Serca Bożego: teorja i rozwój, dz. cyt., s. 404-406; Meta cordium cor Jesu et sanctissima Trinitas, Posnaniae 1683 (nowe wydania uzupełniano dodatkowymi modlitwami do rany boku i Serca Jezusa autorstwa K. Drużbickiego); Gaspar Drużbicki, [w:] Bibliothèque de la Compagnie de Jésus, dz. cyt., t. 3, s. 212-224. 
sercu nowym, sercu, które odnawia wszystkie rzeczy". Nouet podaje też dwanaście przywilejów Serca Jezusa celem ukazania Jego wzniosłości i szlachetności, m.in. jego dziewicze pochodzenie, jego zjednoczenie, jego istnienie w osobie Słowa, które sprawia, że jest „sercem Boga”, jego boską świętość, jego Boże życie, upodobanie, jakie w nim ma Ojciec niebieski, przebywanie Słowa w nim oraz szczególniejsze mieszkanie w nim Ducha Świętego. Natomiast w swych wypowiedziach na temat ran i cierpień Pana przyjmuje idee tradycyjne ${ }^{41}$. Znamienne są tytuły poszczególnych rozdziałów części trzeciej umieszczone przez Noeuta w rozmowach na 22 tydzień po Zesłaniu Ducha Świętego w dziełku La Dévotion envers Notre-Segneur Jésus-Christ. Zawierają one synonimy samego Serca Jezusa, które nazywa on: tronem miłości Bożej, arcydziełem Ducha Świętego, początkiem miłości (bo osobowo złączone ze Słowem), szczególnie wzniosłe (bo płonące najgorętszą miłością ku Bogu) ${ }^{42}$.

Wszystkie pisma Vincenta Huby'ego (1608-1693) przenika duch nabożeństwa do Serca Jezusa, mówią one o Jego miłości lub drodze do jej zdobycia. W Retraite, gdy rozważa o Sercu, wyraża Mu swój żal za swe przewiny i pragnienie miłości, upatruje w Nim źródło swej skruchy i jej dopełnienia. Kontempluje Serce Jezusa „skruszone cierpieniem z powodu naszych grzechów". Ojciec Huby - podobnie jak J. Eudes - zaliczany jest do grona największych czcicieli Serca Jezusa przed Małgorzatą Marią Alacoque ${ }^{43}$.

Bez ogromnego wkładu tak licznych zastępów kapłanów z zakonu benedyktynów, cystersów, dominikanów, franciszkanów i jezuitów kult Serca Bożego nie rozwinąłby się tak, jak to miało miejsce w jego historii,

${ }^{41}$ Por. J. V. Bainvel, Kult Serca Bożego: teorja i rozwój, dz. cyt., s. 409-413, który powołuje się na dieło: J. Nouet, L'homme d'oraison. Ses meditations et entretiens pour tous les jours de l'année, część 2, rozważanie 9 (o przebitym boku), t. 2, Paryż-Lyon 1830, s. 544-550; J. Nouet, [w:] Bibliothèque de la Compagnie de Jésus, dz. cyt., t. 5, s. 1813-1828.

${ }^{42}$ Por. J. V. Bainvel, Kult Serca Bożego: teorja i rozwój, dz. cyt., s. 419, który powołuje się na dzieło: J. Nouet, La Dévotion envers Notre-Segneur Jésus-Christ... pour servir de lecture spirituelle à l'homme d'oraison, Paris 1681, s. 561-570.

${ }^{43}$ Por. J. V. Bainvel, Kult Serca Bożego: teorja i rozwój, dz. cyt., s. 420-434, który odwołuje się do dzieł V. Huby'ego: Oeuvres spirituelles, revues \& corrigées par M. L’abbe, Par. 1758, s. 40-41; La vie des fondateurs des maisons de retraite, par 0 . Champion de la Mahère, Nantes 1698, s. 219-220, La pratique de l'amour de Dieu et de Notre-Seigneur Jésus-Christ, Vannes 1672, Méditations sur l'amour de Dieu pour les retraites, 1690; a także V. Huby, [w:] Bibliothèque de la Compagnie de Jésus, dz. cyt., t. 4, s. 499-505. 
nie miałby tak głębokich korzeni. Kapłani, często zapomniani, których wkład przedstawiliśmy, poprzez swe głębokie świadectwo dali podstawę, co więcej, przygotowali grunt dla doświadczenia z Paray-le-Monial.

Warszawa

WŁODZIMIERZ MOCYDLARZ SI

\section{Słowa kluczowe}

Kapłan, kult, Najświętsze Serca Jezusa, benedyktyni, cystersi, dominikanie, jezuici, duchowość, średniowiecze, mistyk, Małgorzata Maria Alacoque

\section{Summary}

The contribution of religious priests to the development of liturgical worship of Sacred Heart

Contribution by many religious priests (Benedictines, Cistercians, Dominicans, Franciscans and Jesuits) to the devotion of Sacred Heart has improved its theological roots. The article lists priests who conducted the study of Biblical and patristic sources of the cult of Sacred Heart. Their prayer, meditation and contemplation deepened the truth of the Gospel and Tradition. The worship of Sacred Heart is rooted in the Word of God and in it's Patristic interpretation, but it's theological development and the intervention of God through Marguerite Marie Alacoque brought to the approval of the cult by the Church.

\section{Keywords}

Priest, Sacred Heart of Jesus, devotion, worship, Benedictines, Cistercians, Dominicans, Jesuits, spirituality, Middle Ages, mystic, Marguerite Marie Alacoque 